\title{
The Norwegian Thyroid Cancer Project: History, achievements and present view on carcinogenesis
}

\author{
Eystein Glattre \\ Cancer Registry of Norway
}

\begin{abstract}
The Norwegian Thyroid Cancer Project was established in 1985. Its crew has consisted of an interdisciplinary group of scientists, and its secretariat has been part of the Cancer Registry of Norway since day 1 . The aim has been to describe the occurrence of thyroid cancer in Norway, investigate etiological aspects and publish results. Focus has been on the papillary carcinoma of the thyroid, the most incident type of thyroid neoplasia in Norway. Important results of the Project are briefly mentioned. Some forty publications have been produced, mostly epidemiological analyses, but also some experimental studies. The results of the Project and of others have led to the acknowledgement that thyroid carcinogenesis is a complexity-phenomenon partly inaccessible to common scientific procedure.
\end{abstract}

\section{NORSK SAMMENDRAG}

Cancer thyreoidea prosjektet kom igang i 1985. De forskere som har arbeidet innenfor prosjektet, har hatt forskjellig faglig bakgrunn. Prosjektsekretariatet har ligget i Kreftregisteret helt fra starten av. Målsetningen har hele tiden vært å beskrive opptredenen av skjoldkjertelkreft i Norge samt gjøre etiologiske undersøkelser. Fokus har vært på det papillære carcinom som er det hyppigste her til lands. En del viktige forskningsresultater blir kort omtalt. Det er produsert ca. 40 publikasjoner i regi av Prosjektet, den overveiende del er epidemiologiske analyser, i tillegg noen dyreeksperimenter. De samlede erfaringene har ført til den erkjennelse at thyreoidea-karsinogenesen er et kompleksfenomen som bare delvis er tilgjengelig for vitenskapelig forskning.

\section{INTRODUCTION}

From my point of view it is unresistably tempting to contribute to this issue of the Norwegian Journal of Epidemiology, devoted to the commemoration of the National Health Screening Service (SHUS), a public health surveyance and research institute which contributed so much to the national fight against tuberculosis and cardivascular disease in Norway between 1942 and 2001 when it silently seized to be. The Norwegian Thyroid Cancer Project has cooperated twice with SHUS. First time, in the period 1989-93, in a joint investigation testing the hypothesis that seafood increases the risk of thyroid cancer; the second time in the on-going HUBRO-13 project for which the purpose is to describe the thyroid hormone and trace element status in a representative sample of the Oslo population.

\section{Prehistory}

Norwegian clinicians had for long suspected the risk of thyroid cancer to be associated with living conditions in coastal Norway when E. Pedersen, first head of the Cancer Registry of Norway, in 1956 in the Norwegian Medical Society, presented results in favor of this hypothesis. A decade or so later he confirmed and extended his results by successfully showing that thyroid cancer appeared more incident along the coast of Norway than in the inland and more incident in northern Norway compared with southern Norway. He also demonstrated that the papillary carcinoma was the most common type of thyroid cancer, occurring more frequently in the northern than in the southern part of the country (1).

\section{Establishing the Project}

The Norwegian Thyroid Cancer Project was established in 1985. Its crew has from the beginning consisted of an interdisciplinary group of scientists, and its secretariat has been part of the Cancer Registry of Norway since day 1 . The aim of the project has been to disclose and describe the occurrence of thyroid cancer in Norway, investigate etiological aspects of this cancer type and publish results. Focus has been on risk factors associated with so-called differentiated carcinoma of the thyroid, especially the papillary type, which is the most incident in Norway.

The study program started in the beginning of the 1980's with mapping: For the first time in the history of medicine the cancer morbidity of a whole nation was plotted as color-maps by means of newly developed, computer-cartographic methods. The Atlas of Cancer Incidence in Norway 1970-79, which was pub- 
lished in 1985, also contains maps that show thyroid cancer incidence by sex in the country. The thyroid maps show clearly high-risk patterns that are evidently not accidental. Most conspicuous is a high-risk zone that, with some breaches, follows the coastline from the Norwegian-Swedish border at Skagerrak to the Norwegian-Russian border at the Barents Sea. In North-Norway a few high-risk areas with incidence rates matching the rates of high-risk Melanesian islands (e.g. Fiji) (2), extend from coast to inland. In the southern part of Norway one easily sees a vast inland area with incidence rates above average just east of the watershed formed by the Caledonian mountain range (3). The discovery of the coastal overrisk has been the overriding challenge for most of the studies of this Project ever since.

Our first approach to the problem concerning the coastal over-risk was reductionist and correlational. In 1985-86 we were able to show that the incidence of the papillary carcinoma, but not that of the follicular, medullary and anaplastic carcinoma of the thyroid, increased from the southernmost to the northernmost counties of Norway. This observation turned out to be fairly easy to explain. By computing and aggregating papillary carcinoma incidence rates for Norway's approximately 440 municipalities according to their main trade, it became clear that this incidence was lowest in agricultural and highest in fishing municipalities for which the rate was fairly constant irrespective of geographical coordinates. Since the density of fishing municipalities increases substantially from south to north of Norway, we had in fact reduced both the problem of coastal over-risk and of the south-to-north risk gradient to a question as to why the incidence of papillary carcinoma is high in fishing municipalities $(4,5)$.

\section{JANUS BANK STUDIES}

The high incidence of thyroid cancer in fishing municipalities lend support to our hypothesis that a high intake of seafood tends to increase the risk of papillary carcinoma. A plan was therefore designed to develop a program that identifies mechanisms that destabilize/ stress the thyroid follicle cells and make them more prone to malignant change when exposed to components of seafood.

In 1986 the Project got the necessary permissions to utilize sera from the Janus serum bank, established 1973 , in the freezers of which more than 100.000 healthy Norwegians at that time had deposited one or more serum samples, routinely taken in connection with health control. Matching the Janus register with the Cancer Registry made it possible to identify 43 persons who had later developed thyroid cancer, plus 128 cancer-free controls all of whom had sera deposited in the Janus bank. The cases developed thyroid cancer on average 4.8 years after donation of serum to Janus. The main finding of this study (6) was the elevated levels of serum thyroglobulin in cases as com- pared to controls - several years prior to diagnosis. On the other hand, there was no statistically significant difference between the serum-TSH concentration of cases and that of controls. It is tempting to add that more than ten years after publication this paper, which is part of the doctoral thesis of $\mathrm{K}$. Rootwelt, remains the only one of its kind in thyroid literature (IARC scientific publication no 147, 1999).

In 1989 we published our second study of the same 43 thyroid cancer cases and their 128 controls, this time with regard to the trace elements selenium and copper (7). In agreement with our hypothesis the cases were significantly lower in serum selenium than controls, and the odds ratio of thyroid cancer increased from 1 for s-levels $\geq 1.65 \mu \mathrm{mol} / 1$, to 6.1 for s-levels $1.26-1.64 \mu \mathrm{mol} / 1$, to 7.7 for $\mathrm{s}-\mathrm{levels} \leq 1.25 \mu \mathrm{mol} / \mathrm{l}$. It was shown that the protective effect of high serum selenium levels was restricted to the last seven years prior to diagnosis of thyroid cancer. There was no difference between cases and controls with regard to serum copper. The 1990-study of selenium concentrations in the human thyroid gland, showing that the gland is the most selenium-rich tissue in the human body (8), together with this case-control study have contributed significantly to the present interest in the significance and function of selenium in thyroid gland pathophysiology. Papers $(7,8)$ are not infrequently referred to.

Fish meals tend to increase serum concentrations of the long-chain fatty acids eicosapentaenoic acid (EPA) (20:5,n-3) and docosahexaenoic acid (DHA) (22:6,n3). Early in the 1990's we worded the hypothesis that increasing serum concentrations of n-3 fatty acids are associated with increasing risk of thyroid papillary carcinoma. It was tested in a nested case-control study with 74 case-sera and 221 matched control-sera, all drawn from the Janus serum bank. The main results were i) that a high EPA/AA ratio, allegedly indicating consumption of fish fat, is associated with an increased (non-significant) thyroid cancer risk, and ii) that a significant, inverse relationship exists between the sum of the serum concentrations of arachidonic acid (AA) (20:4,n-6) and DHA and the risk of papillary carcinoma. The study was published in 1994 (9).

Pharmacological doses of dehydroepiandrosterone (DHEA) from the adrenal glands have allegedly reduced the incidence of chemically induced thyroid cancer in animal studies. We therefore decided to test whether higher, serum DHEA-sulfate concentrations are associated with decreased thyroid cancer risk and used a population-based case-control study with 113 case-sera and 339 control-sera, each case matched with 3 controls, taken from the Janus serum bank. There was no significant association, however, between concentrations of pre-diagnostic serum DHEA-S and thyroid cancer. The study was published in 1999 (10). By means of the same material we have also tested whether serum albumin is inversely associated with (types of) thyroid cancer. The hypothesis had to be rejected (11). 


\section{THE EXPERIMENTAL ARM}

In the late 1980's we started doing experiments on animals and cells. This investigative initiative, normally not part of epidemiological studies, was a consequence of the reductionistic strategy designed very early in the history of the project. In the late 1980's we deduced a sub-hypothesis to the seafood hypothesis, namely that marine, fatty acids increase the risk of thyroid neoplasms as compared with terrestrial, unsaturated fatty acids, and tested it in a rat experiment in which one group got n-3 and one group got n-6 fatty acids. All rats were fed a goitrogen and a mutagen (nitrosomethylurea). The study, published in 1990 (12), did not demonstrate any difference in risk between the two groups. It was criticized, however, for having applied too high a dose of mutagen. In retrospect, however, the study appears not to be incompatible with the results in publication (9) demonstrating a preventive effect of the combination of DHA and AA with regard to papillary carcinoma. At the same time FRTL-5 rat thyroid cells were imported from Denmark for studies of aspects of thyroid cell physiology and carcinogenesis. J.P. Berg utilized the FRTL-5 cells in his investigation of vitamin $\mathrm{D}$ as regulator of the TSH/cAMP signal system in follicle cells. The studies constitute his doctoral thesis that was defended in 1995 (13).

In 1995 we published a study (14) of the distribution and interaction of arsenic and selenium in the rat thyroid. This was meant as supplement to previous selenium studies, and was based on one of the subhypotheses that can be deduced from the seafood hypothesis: Seafood has been the main human source of arsenic in the second half of the twentieth century. Hence, marine As may contribute to thyroid carcinogenesis in coastal populations. Our experiment indicate that inorganic As and Se both tend to accumulate in thyroid tissue, the follicle cell nuclei of which can be seriously damaged by an overload of arsenate and arsenite.

In 1997 we began a series of animal experiments in close cooperation with Vladislav Eybl's scientific group in Pilsen in the Czech Republic. The purpose has all the way been to describe and interpret variations in thyroid related hormones and other variables when follicle cells are overexposed to long-term consumption of and destabilized by exposure to arsenic, tellurium or sub-optimal daily doses of selenium (15). At present we are finalizing a 2-generation Wistar rat experiment with the purpose to gain more information as to i) the vulnerability of the offspring of I-exposed dames and ii) the variability of the Wolff-Chaikoff adaptation mechanism of the individual rat follicle cells. This variability may have significance for papillary carcinogenesis. Our model indicates that a delayed adaptation or relative insensitivity to iodine exposure of some of the cells may be significant as to the proneness of the thyroid tissue to turn malignant.

\section{STUDIES AND META-STUDIES AT THE END OF A CENTURY}

Investigations have produced several papers of which two may be more important from an etiologic point of view. A cohort study published in 1991 is the first of these: It showed a positive correlation between female parity and the incidence of thyroid cancer. The study confirmed and extended findings of others, that the relative risk increased for each pregnancy from the childless woman to the woman with four or more children, more for the follicular than the papillary carcinoma. Our data indicate that parity has virtually the same effect at all ages and in all birth cohorts (16). No other paper on female parity has come close to the size and solidity of this paper. Three years later the paper was supplemented with a study of male parity (17) showing no correlation between male parity and risk of thyroid cancer. It was concluded that the female parity effect must be ascribed endogenous factors associated with pregnancy, delivery and/or lactation.

We began our research cooperation with SHUS in the late 1980's. SHUS provided us with individual dietary information that made possible our joint study 'Norwegian case-control study testing the hypothesis that seafood increases the risk of thyroid cancer'. This paper from 1993 (18) suggests that consumption of fish and fish products tend to increase a person's risk of thyroid cancer in iodide-rich areas. The risk increases by the number of fish-meals per week. The outcome is compatible with the results published in the study of the thyroid cancer risk of fishermen's wives, published in 1997 (19): In Norway spouses of fishery workers have a higher risk than women married to men of any other main occupational class. The results also suggest that the increased risk is restricted to the older birth cohorts of spouses while younger wives seem to have a risk closer to the population average. In congruence with this the incidence of thyroid carcinoma among women has been declining in later years.

L.A. Akslen finished in 1993 his doctoral studies by defending the thesis 'Thyroid cancer. A study of incidence pattern, pathological features and prognosis'. The thesis contains 7 epidemiological articles on aspects of thyroid cancer half of which put emphasis on describing important aspects of thyroid cancer occurrence in time and space. The remaining articles are devoted to studying pathological features of the papillary and follicular carcinoma and the prognosis of thyroid cancer with special reference to clinical and pathological features (20).

A couple of studies as to the risk of thyroid cancer among patients with renal transplant, show that special immunosuppressive treatments tend to increase the risk significantly, especially among men (21).

The Project communicated the (anonymised) material of the SHUS-Cancer Registry paper (18) plus additional data on diet to the project called 'Pooled 
analysis of thyroid cancer studies' the organization of which was initiated by dr. Elaine Ron, NCI in Bethesda, USA, in the beginning of the 1990's. In addition, E. Negri and S. Franceschi contributed to the collection and implementation of the greatest metaanalytical investigation in the history of thyroid cancer. Meta-analysis itself was carried out by Italian epidemiologists and statisticians (22-25).

In the late 1990's we also carried out one of the greatest studies ever of the familiality of nonmedullary thyroid cancer risk (FNMTC). The study shows that heredity plays a minor role in thyroid cancer except for the medullary type (26).

In the year 2000 began a new joint research venture with SHUS. It has been named HUBRO-13 because it is the thirteenth appendical project to the main investigation HUBRO, health survey of Oslo citizens, led by SHUS. Blood- and urine-specimens have by now been collected from a representative sample of 2500 Oslo citizens with the purpose to describe the status of the individual with regard to thyroid hormones and trace elements. These data, available for analysis in 2004, will be linked to information on health and diet, provided by other researchers connected with HUBRO. The 2500 individuals will be surveyed for many years with regard to health.

\section{SELECTED ACHIEVEMENTS}

- Establishing and corroborating the hypothesis that a preventive influence on thyroid cancer appears to be exerted by higher serum concentrations of selenium. The effect is possibly related to the fact that Se is cofactor for enzymes fighting oxygen radical byproducts from the $\mathrm{H}_{2} \mathrm{O}_{2}$-TPO iodification of thyroid hormones.

- Finding increasing papillary carcinoma risk associated with increasing consumption of seafood (iodinerich area).

- Finding that increasing female parity (probably hormones of pregnancy and lactation) increases both the papillary and the follicular carcinoma risk, and that the removal of ovaries and uterus eliminates female over-risk.

- The thyroid gland as target tissue for selenium, arsenic and tellurium (neighbors in the periodic system) (14,27).

- The negative relation between pre-diagnostic level of arachidonic plus docosahexaenoic fatty acids and subsequent risk of papillary carcinoma (9).

- Low familial over-risk for non-medullary thyroid cancer (26).

- Serum-thyroglobulin as a preclinical tumour marker (6).

- Increased risk of thyroid cancer, especially among males, after renal transplantation (21).

- Lack of association between level of pre-diagnostic serum dehydroepiandrosterone sulfate (DHEA-S) and subsequent thyroid cancer (10).
The Project has until this year produced altogether forty articles and book-chapters, mostly in English. Selected papers are commented on in Cancer Epidemiology and Prevention (D. Schottenfeld \& J.F. Fraumeni, editors), Chapter 46, N.Y., 1996 and Food, Nutrition and the Prevention of Cancer: a global perspective, Section 4,16, World Cancer Research Fund/American Institute for Cancer Research, 1997.

\section{VIEWPOINTS ON THYROID CARCINOGENESIS}

The multifactorial carcinogenesis of thyroid cancer is far from linear. It is more to liken with a landslide of a multitude of events a majority of which are individual and solitary, only. The landslide pattern of events will therefore be different from person to person, age-group to age-group, even for the same type of carcinoma. From our model perspective the number of unspecifiable events that take part in the etiological process of the tumours, is huge. It is, in other words, complexity, not simplicity, that characterises the thyroid carcinogenic process - in our opinion even when ionizing radiation is involved. Scientific research on the development of thyroid cancer must therefore be restricted to such etiological events that are shared by many tumors. Some of these may be called 'beacon-events' because they are frequently present in the carcinogenic landslide. We have so far established several possible candidates for the 'beacon-event' title, for instance:

In animal experiments J. Kanno et al. (28) have shown that iodine in the diet contributes to the occurrence of thyroid neoplasia in a special way. The curve showing the percentage of rats with lesions is bimodal with one peak in the low range of iodine intake, that is approximately $1-10 \mu \mathrm{g} / \mathrm{rat} / \mathrm{day}$, and one in the range from around $1000 \mu \mathrm{g} / \mathrm{rat} /$ day and upwards. With this background we assume that the iodide concentration that initiate the release of the Wolff-Chaikoff block, vary from follicle cell to follicle cell. Thus, the relative protection against cellular damage caused by high iodide concentrations, will be best in the lower part of the concentration interval over which the sensivity of the follicle cells are distributed. In the follicle cell population of the thyroid gland the most vulnerable cells are consequently the cells with an iodine insensitive Wolff-Chaikoff mechanism. When sufficiently many cells turn on the Wolff-Chaikoff block, the thyroid output of TH tends to diminish causing a compensatory outpouring of TSH from the pituitary. The unprotected cells may therefore be exposed both to high iodide concentrations and elevated TSH. If exposure to iodide is repeated over and over again, mutations due to oxygen radicals hitting some of the unprotected follicular cells, are likely. For I-concentrations above this sensitivity interval all cells are protected by the block until the I-concentration becomes so high that the Wolff-Chaikoff defense mechanism breaks down. The frequency of lesions will again begin to increase. 
High I-exposure levels damage follicle cells and cause TSH to rise and mutagenic/carcinogenic substances, e.g. alkylating halides, to be synthesized in joint action with the $\mathrm{H}_{2} \mathrm{O}_{2} /$ TPO system. Preliminary study results indicate that for extremely high levels of iodide, rat-TSH increases significantly after a delay of three or more weeks (29).
Summing up: On given conditions doses of iodide tend to depress the T4 and T3 serum-concentrations and cause a compensatory, goitrogenic increase in TSH. These doses will involve an overexposure of harmful radicals and halogen containing carcinogens to especially susceptible follicle cells.

\section{REFERENCES}

1. Pedersen E, Hougen A. Thyroid Cancer in Norway. UICC Monograph Series, V12 (Hedinger C, ed.), Heidelberg, 1969, 72-4.

2. Glattre E, Thoresen SØ, Jebsen JW. Thyroid cancer: High risk areas in northern Norway. In: Excess and deficiency of trace elements in relation to human and animal health in Arctic and Subarctic regions (Låg J, ed.), The Norwegian Academy of Science and Letters, Oslo, 1990.

3. Glattre E, Finne TE, Olesen O, Langmark F. Atlas over kreftinsidens i Norge 1970-79 (with English summaries). The Norwegian Cancer Association, Oslo, 1985.

4. Glattre E, Thoresen SØ, Johansen Aa. Incidence of thyroid cancer in Norway 1970-79. Geographical distribution of histologic types. In: Proceedings of the $1^{\text {st }}$ international symposium on geochemistry and health (Thornton I, ed.), Monograph Series: Environmental Geochemistry and Health, London, 1985.

5. Thoresen SØ, Glattre E, Johansen Aa. Thyreoidea cancer i Norge 1970-79. Tidsskr Nor Lageforen 1986; 106 (31): 2616-20.

6. Thoresen SØ, Myking O, Glattre E, Rootwelt K, Andersen Aa, Foss OP. Serum thyroglobulin as a preclinical tumour marker in subgroups of thyroid cancer. Br J Cancer 1988; 57: 105-108.

7. Glattre E, Thomassen Y, Thoresen SØ, Haldorsen T, Lund-Larsen PG, Theodorsen L, Aaseth J. Prediagnostic serum selenium in a case-control study of thyroid cancer. Int J Epidemiol 1989; 18: 45-49.

8. Aaseth J, Frey H, Glattre E, Norheim G, Ringstad J, Thomassen Y. Selenium concentrations in the human thyroid gland. Biol Trace Elem Res 1990; 24: 147-152.

9. Berg JP, Glattre E, Haldorsen T, Høstmark AT, Bay IG, Johansen AF, Jellum E. Longchain serum fatty acids and risk of thyroid cancer: a population-based case-control study in Norway. Cancer Causes Control 1995; 5: 433-439.

10. Berg JP, Engeland A, Jellum E, Glattre E. Serum dehydroepiandrosterone sulfate concentration and thyroid cancer risk: a matched case control study. Thyroid 1999; 9: 285-288.

11. Glattre E, Engeland A, Jellum E, Høstmark AT. Serum-albumin and risk of thyroid cancer: A populationbased, matched case-control study. Norsk Epidemiologi 2001; 11: 197-200.

12. Glattre E, Høstmark AT, Thoresen SØ, Smith AJ, Akslen LA. Provocation of thyroid neoplasms in female Wistar rats fed n-3 or n-6 fatty acids in the feed. Thyroidology 1990; 2: 1-3.

13. Berg JP. Vitamin D - A Novel Hormonal Regulator of the TSH/cAMP signaling Pathway in Thyroid Cells. Doctoral Thesis, Oslo University, 1995.

14. Glattre E, Mravcova A, Lener J, Vobecky M, Egertova E, Mysliveckova M. Study of distribution and interaction of arsenic and selenium in rat thyroid. Biol Trace Elem Res 1995; 49: 177-186.

15. Eybl V, Kotyzova D, Koutensky J, Caisova D, Topolcan O, Holubec L, Glattre E. Effect of longterm administration of arsenic (III), bromine and iodine on TSH and thyroid hormones level and oxidative state in rats. Toxicol Lett 1999; 109 (Suppl 1): 50.

16. Kravdal Ø, Glattre E, Haldorsen T. Positive correlation between parity and incidence of thyroid cancer: New evidence based on complete Norwegian birth cohorts. Int J Cancer 1991; 49: 831-836.

17. Glattre E, Kravdal Ø. Male and female parity and risk of thyroid cancer. Int J Cancer 1994; 58: 616-617.

18. Glattre E, Haldorsen T, Berg JP, Stensvold I, Solvoll K. Norwegian case-control study testing the hypothesis that seafood increases the risk of thyroid cancer. Cancer Causes Control 1993; 4: 11-16.

19. Frich L, Akslen LA, Glattre E. Increased risk to thyroid cancer among Norwegian women married to fishery workers - a retrospective cohort study. Br J Cancer 1997; 76: 385-389.

20. Akslen LA. Thyroid cancer. A study of incidence pattern, pathological features and prognosis. Doctoral Thesis, Bergen University, 1993.

21. Birkeland SA, Storm HH, Lamm LU, Barlow L, Blohme I, Forsberg B, et al. Cancer risk after renal transplantation in the Nordic countries, 1964-1986. Int J Cancer 1995; 60: 183-189.

22. Negri E, Ron E, Franceschi S, Dal Maso L, Mark SD, Preston-Martin S, et al. A pooled analysis of casecontrol studies of thyroid cancer. I. Methods. Cancer Causes Control 1999; 10: 131-142. 
23. Negri E, Dal Maso L, Ron E, La Vecchia C, Mark SD, Preston-Martin S, et al. A pooled analysis of casecontrol studies of thyroid cancer. II. Menstrual and reproductive factors. Cancer Causes Control 1999; 10: 143-155.

24. Franceschi S, Preston-Martin S, Dal Maso L, Negri E, Vecchia C, Mack WJ, et al. A pooled analysis of casecontrol studies of thyroid cancer. IV. Benign thyroid diseases. Cancer Causes Control 1999; 10: 583-595.

25. Dal Maso L, La Vecchia C, Franceschi S, Preston-Martin S, Ron E, Levi F, et al. A pooled analysis of thyroid cancer studies. V. Anthropometric factors. Cancer Causes Control 2000; 11: 137-144.

26. Frich L, Glattre E, Akslen LA. Familial occurrence of non-medullary thyroid cancer. A population-based study of 5673 first-degree relatives of thyroid cancer cases from Norway. Cancer Epidemiol Biomarkers Prev 2001; 10: 113-7.

27. Eybl V, Kotyzova D, Sykora J, Pikner R, Mihaljevic M, Koutensky J, et al. Effect of long-term administration of sodium tellurite and selenite on iodine cumulation and thyroid status in rats. Proceedings, Eurotox 2000.

28. Kanno J, Onodera H, Furuta K, Maekawa A, Kasuga T, Hayashi Y. Tumor-promoting effects of both iodine deficiency and iodine excess in the rat thyroid. Toxicol Pathol 1992; 20: 226-35.

29. Glattre E, Eybl V, Kotyzova D, Mihajlevic M, Pikner R, Topolcan O. Blood serum level of TSH and thyroid hormones and thyroid tissue content of iodine in rats under restricted selenium and iodine supply. Norsk Epidemiologi 2001; 11: 201-4. 